\title{
Frequency variation of mechanical waves of the impulse tomograph based on geographic north
}

\author{
Variação da frequência de ondas mecânicas do tomógrafo de impulso \\ em função do norte geográfico
}

\author{
Flavio Henrique Mendes ${ }^{1}$ and Demostenes Ferreira da Silva Filho ${ }^{1}$
}

\begin{abstract}
RESUMO
Madeira de tração e madeira oposta são tecidos especializados desenvolvidos em angiospermas. O primeiro ocorre no lado superior, enquanto o segundo, no lado inferior. Este artigo analisou a influência dos ventos predominantes de leste e sudeste na formação de madeira de tração e madeira oposta em troncos de árvores de angiospermas em uma cidade tropical, por meio da matriz de tomografia de impulso, em seções transversais. O uso da imagem tomográfica é interessante para avaliar a saúde das árvores, pois é uma metodologia não destrutiva e abrangente. Um total de 27 árvores foi analisado, sendo uma de cada espécie, em um parque urbano em Piracicaba/SP/Brasil. O valor de R-quadrado da regressão linear entre a densidade básica e a velocidade de propagação de onda das árvores foi de 0,3271 , revelando que cada árvore é um caso específico e que a análise deve ser feita de forma individualizada. Uma vez obtida as imagens tomográficas, estas foram divididas em quadrantes: em $70 \%$ dos casos houve predominância dos valores mais altos para a velocidade de propagação de ondas mecânicas nos quadrantes 2 e 3, revelando e provando a influência dos ventos predominantes de leste e sudeste.
\end{abstract}

Palavras-chave: Crescimento adaptado; Velocidade da onda mecânica; Estabilidade da árvore; Arborização urbana; Densidade básica da madeira.

\begin{abstract}
Tensile wood and opposite wood are specialized tissues developed in angiosperms. The first occur on the upper side, while the second, the lower side. This paper analyzed the influence of the prevailing east/southeast winds on the formation of tension wood and opposite wood in tree trunks of angiosperms in a tropical city, using an impulse tomography array, in cross sections. The use of tomographic imaging has gained support for evaluating tree health as it is a non-destructive and comprehensive methodology. A total of 27 trees were analyzed, being one of each species, in a urban park at Piracicaba/SP/Brazil. The R-squared value of the linear regression of basic density and wave propagation speed from the trees was 0.3271 , revealing that each tree is a specific case and the analysis must be done in an individualized mode. Once obtained the tomographic images, they were divided into quadrants: in $70 \%$ of cases there was a predominance of highest values for mechanical wave propagation speed in quadrants 2 and 3 , revealing the proving influence of the predominant east and southeast wind.
\end{abstract}

Keywords: Adaptative growth; Mechanical wave speed; Tree stability; Urban forestry; Wood basic density.

\section{INTRODUCTION}

Urban forestry provides temperature attenuation, more aesthetically pleasing landscapes, adding value to adjacent buildings, capture pollutants, protect urban areas from direct sunlight and the impact of precipitation, extending the life of the pavement (GOOD, 2010) and also barriers strong winds (KUHNS, 2010).

Trees are exposed to various stresses (such as wind), being influenced by tension, compression, shear, bending and twisting. In order to prevent breakage of the root and trunk, they compensate these stresses by creating internal tensions by modifying their shape, size and structure, called adaptive growth (MATTHECK; BRELOER, 1997). In this context, impulse tomography is a non-destructive method, able to assess decay, allowing a trained professional to predict the tree stability, based on the

1. Forestry Department, Escola Superior de Agricultura "Luiz de Queiroz" - ESALQ, Univesidade de São Paulo - USP. Piracicaba / SP, Brazil. Corresponding author: friquemendes@usp.br 
principle of timing mechanical waves and reconstruction of sections of trees to generate a tomographic image. Wave propagation time is strongly correlated with the density of the material, however, the results must be interpreted by a specialist in the area (RINNTECH COMPANY, 2005). Amodei et al. (2010) and Pereira et al. (2007) and Pereira-Rollo et al. (2014) obtained satisfactory results about the quality of wood using the impulse tomography, while Wang and Alison (2008) found areas of decay in the sections analyzed.

The basic wood density (BD) is defined as the ratio between dry weight and the saturated volume $\left(\mathrm{g} \mathrm{cm}^{-3}\right.$ or $\mathrm{kg} \mathrm{m}^{-3}$ ), increasing from pith to bark (VALE et al., 2009) and decreasing towards bottom-up, due to the higher amount of juvenile wood at the tree top (JYSKE et al., 2008).

The aim of the study was verify the influence of prevailing winds in the creation of tension wood and opposite wood in the trunks of angiosperms trees in a tropical city.

\section{MATERIAL AND METHODS}

A tomographic scan was made in 2013, of 27 trees in the urban park - campus of ESALQ / USP (Luiz de Queiroz College of Agriculture / University of Sao Paulo) in Piracicaba city / São Paulo state / Brazil, geographic coordinates $22^{\circ} 42^{\prime} 30^{\prime \prime} \mathrm{S}$ and $47^{\circ} 38^{\prime} 00^{\prime \prime} \mathrm{W}$, Köppen climate classification Cwa (subtropical humid with dry winter), $554 \mathrm{~m}$ above sea level, average annual rainfall of $1328 \mathrm{~mm}$ and mean minimum and maximum annual temperatures of $14.8^{\circ} \mathrm{C}$ and $28.2^{\circ} \mathrm{C}$, respectively (CEPAGRI, 2009). The vegetation is semideciduous forest located in the area known as the Paulista Peripheral Depression (OLIVEIRA; PRADO, 1989).

The materials needed were: map with the geographic location of the trees, impulse tomography equipment and tablet, which was connected via USB port of the scanner in order to record the behavior of waves through Arbotom software embedded (developed by Rinntech Company) for subsequent analysis.

The impulse tomography has 12 interconnected sensors, of which at least 8 must be fastened to the trunk via nails, with the fastened sensors circling the entire tree trunk. A light touch of a hammer on each of the nails (that pierce the bark) causes internal mechanical wave propagation with other sensors. As the mechanical resistance changes so does the total propagation time. Adult specimens were preferentially selected to reduce variation of basic density between individuals.

The viewer software (Arbotom) processed the data and presented as maps showing the current state of the cross section analyzed. The manual recommends that to increase the confidence in the results, the speed obtained from each sensor must be $<10 \%$ of the standard deviation (RINNTECH COMPANY, 2005). In ascending order, we selected $20 \%$ of intermediate values obtained for wave propagation speeds, to converge in a most real value to represent the species (Table 1):

All 27 analyzed trees, being one of each species, were in flat relief and with balanced crowns. We chose these species because of their availability on campus and their respective values of basic density in the literature, to do the correlations. After the completion of the 27 scans, the trunk sections tomographic images were analyzed and correlated opposite wood and prevailing winds directions in the region.

\section{RESULTS AND DISCUSSION}

Figures 1 and 2 show the comparision between two species of trees, with the array setup and thematic map generated. In order to standardize the results to allow comparisons and correlations, all images of tomographies scans were oriented to geographic north: in the field, the compass was positioned on sensor 1, indicating the position of magnetic north and, then, we did the convertion, being the magnetic declination for Piracicaba equal $20.6^{\circ} \mathrm{W}$ (NOAA, 2014).

Knowing the distance between sensors and respective mechanical wave timings, it is only divide distance for timing to get the wave speeds $\left(\mathrm{m} \mathrm{s}^{-1}\right)$, as showed in the tomographic image scale. By figures 1 and 2, we verified that the propagation velocities of the mechanical wave were smaller in Aspidosperma polyneuron than Cariniana legalis. Although the basic density is close to each other (respectively, 0.83 and $0.78 \mathrm{~g} \mathrm{~cm}^{-3}$ ), probably the efforts of nature, especially prevailing winds, exert a greater influence on Cariniana legalis. In image 1, the dark part (black and brown) corresponds to opposite wood, i.e., in this case, the opposite part of prevailing winds direction. 
Table 1. Results of species tomographic measurements with corresponding basic density

Tabela 1. Resultados das medidas tomográficas das espécies com densidade básica correspondente

\begin{tabular}{|c|c|c|c|}
\hline Scientific name & BD Source & $\begin{array}{c}\text { BD } \\
\left(\mathrm{g} \mathrm{cm}^{-3}\right)\end{array}$ & $\begin{array}{c}\text { Average speed } \\
\left(\mathrm{m} \mathrm{s}^{-1}\right)\end{array}$ \\
\hline Libidibia ferrea (Mart. ex Tul.) L.P. Queiroz) & Ipef & 1.12 & 1763.88 \\
\hline Paubrasilia echinata Lam. & Ipef & 1.10 & 2081.25 \\
\hline Hymenaea courbaril L. & Ipef & 1.00 & 1513.77 \\
\hline Poecilanthe parviflora Benth. & Lorenzi, 1992 & 0.99 & 1609.44 \\
\hline Astronium graveolens Jacq. & Ipef & 0.97 & 1453.31 \\
\hline Myrocarpus frondosus Allemão & Ipef & 0.95 & 1389.75 \\
\hline Pouteria caimito (Ruiz \& Pav.) Radlk. & SFB & 0.88 & 1883.33 \\
\hline Dalbergia nigra (Vell.) Allemão ex Benth. & Ipef & 0.87 & 1680.44 \\
\hline Lecythis pisonis Cambess. & SFB & 0.84 & 1446.19 \\
\hline Aspidosperma polyneuron Müll. Arg. & Ipef & 0.83 & 796.19 \\
\hline Cariniana legalis (Mart.) Kuntze & Ipef & 0.78 & 1281.56 \\
\hline Cariniana estrellensis (Raddi) Kuntze & Ipef & 0.78 & 1231.06 \\
\hline Ormosia arborea (Vell.) Harms & Lorenzi, 1992 & 0.70 & 1159.88 \\
\hline Holocalix balansae Micheli & Embrapa Forestry & 0.69 & 1472.38 \\
\hline Peltophorum dubium (Spreng.) Taub. & Ipef & 0.69 & 1076.63 \\
\hline Swietenia macrophylla King & Ipef & 0.63 & 1581.74 \\
\hline Enterolobium contortisiliquum (Vell.) Morong & Ipef & 0.60 & 717.56 \\
\hline Mangifera indica L. & FAO, 1997 & 0.55 & 945.25 \\
\hline Anadenthera colubrine (Vell.) Brenan & Ipef & 0.52 & 1520.37 \\
\hline Joannesia princeps Vell. & Ipef & 0.48 & 1270.44 \\
\hline Calophyllum Spruceanum Benth. & Andrade; Carvalho, 1998 & 0.46 & 1715.81 \\
\hline Gmelina arborea Roxb. ex Sm. & FAO, 1997 & 0.41 & 1530.44 \\
\hline Sterculia chicha A. St.-Hil. ex Turpin & Lorenzi, 1992 & 0.39 & 1250.75 \\
\hline Spondias mombin $\mathrm{L}$. & SFB & 0.38 & 1071.06 \\
\hline Ceiba speciosa (A. St.-Hil.) Ravenna & Ipef & 0.34 & 871.63 \\
\hline Schizolobium parahyba (Vell.) S.F. Blake & Ipef & 0.32 & 931.88 \\
\hline Ceiba pentandra (L.) Gaertn. & SFB & 0.29 & 823.56 \\
\hline
\end{tabular}

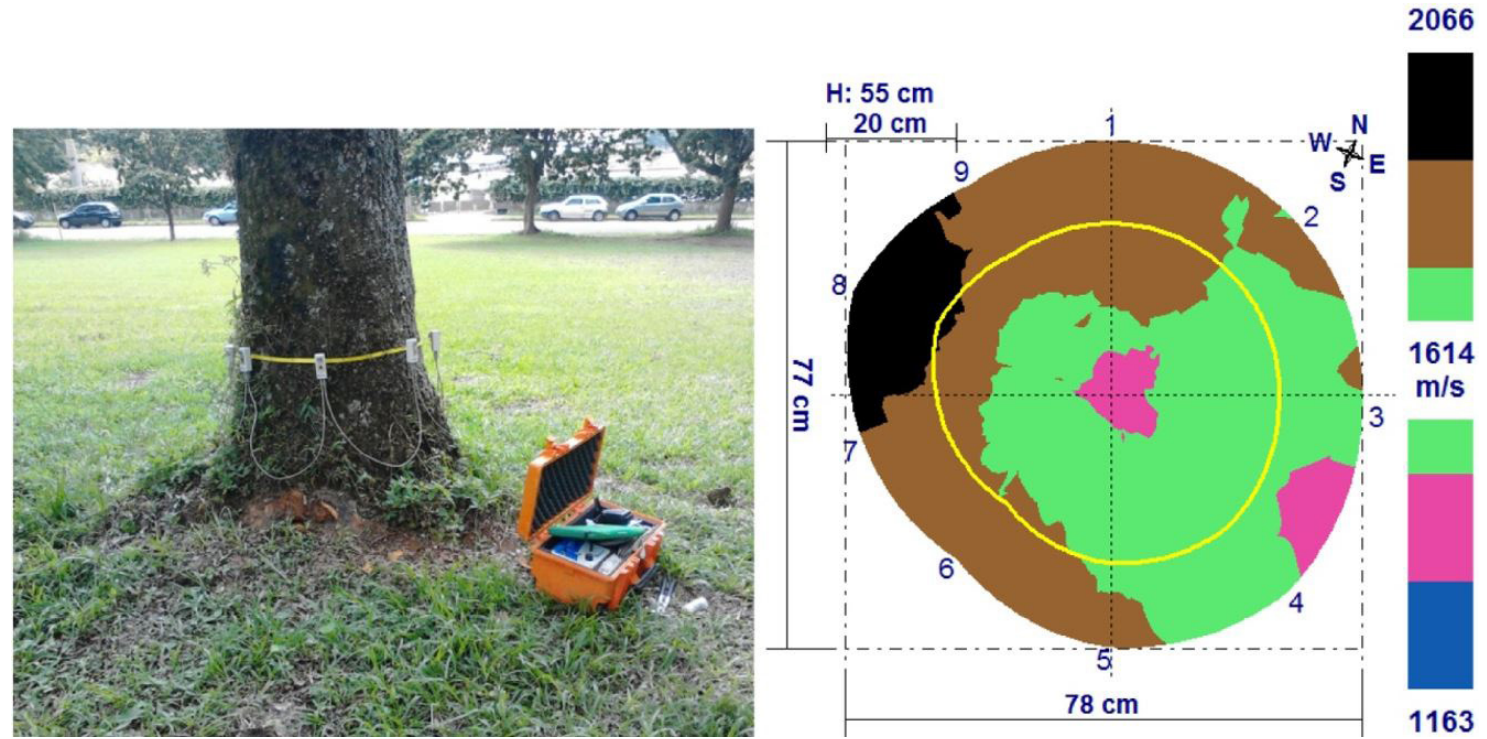

Figure 1. Tomography image of the cross section in the Pink-jequitibá tree (Cariniana legalis (Mart.) Kuntze), 55 cm above the ground, with the internal mechanical wave propagation speed

Figura 1. Imagem da tomografia na seção transversal em jequitibá-rosa (Cariniana legalis (Mart.) Kuntze), a 55 cm acima do solo, com a velocidade de propagação da onda mecânica interna

Tensile wood and opposite wood are specialized tissues developed in angiosperms. The first occur on the upper side, while the second, the lower side. The tension wood corresponds to the part of the tree that is under stronger tension stress, while the opposite wood, lower tensile stressed (CLAIR et al., 2006), occurring a dislocation of the angle from the pith to the centroids of the wood, i.e., the pith will be found near the opposite wood of the tensile. This particular type of wood (tension tissue) is characterised by the occurrence of fibres with an individual morphology and chemical composition 

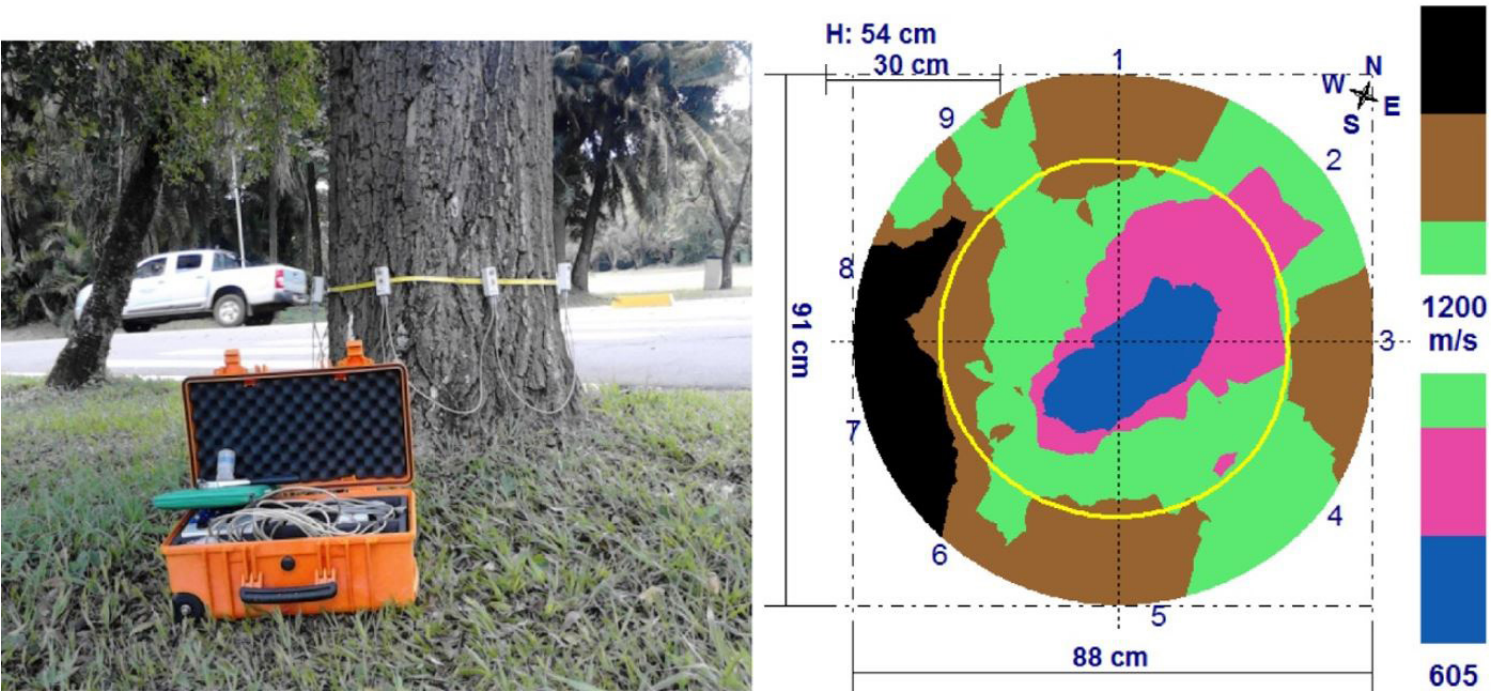

Figure 2. Tomographic image of the interior of a Pink-peroba tree (Aspidosperma polyneuron Müll. Arg.), measured at a height of $54 \mathrm{~cm}$ above the ground

Figura 2. Imagem da tomografia do interior da peroba-rosa (Aspidosperma polyneuron Müll. Arg.), medida à altura de $54 \mathrm{~cm}$ acima do solo

due to the development of the gelatinous layer (G-layer) (RUELLE, 2014), although this layer is not really clear from observations in all angiosperms, based on classical anatomy (CLAIR et al., 2006).

In spite of the literature is scarcity about quantitative data of Impulse Tomography technique, most probably because it is a high-tech equipment and, consequently, a high purchase price, which is not always available to everyone, the equipment was clearly efficient in identifying different zones, as suggested by Castro et al. (2011). For Cariniana legalis, the part with greater density lies in quadrant 2, whereas for Aspidosperma polyneuron, quadrant 3, both suggesting easterly and southeastly winds, as reported by Wiendl and Angelocci (1995) in the local. Through visual analysis, all trees appeared to be healthy, without structural problems or decay resistance. For comparative purposes, the scans of trees with relatively high and low densities were respectively: Paubrasilia echinata Lam. (Figure 3A) and Schizolobium parahyba (Vell.) S.F. Blake (Figure 3B). The height (H) at which the scan was performed on $S$. parahyba $(89 \mathrm{~cm})$ was above the other species because of the existence of superficial roots forming buttresses.
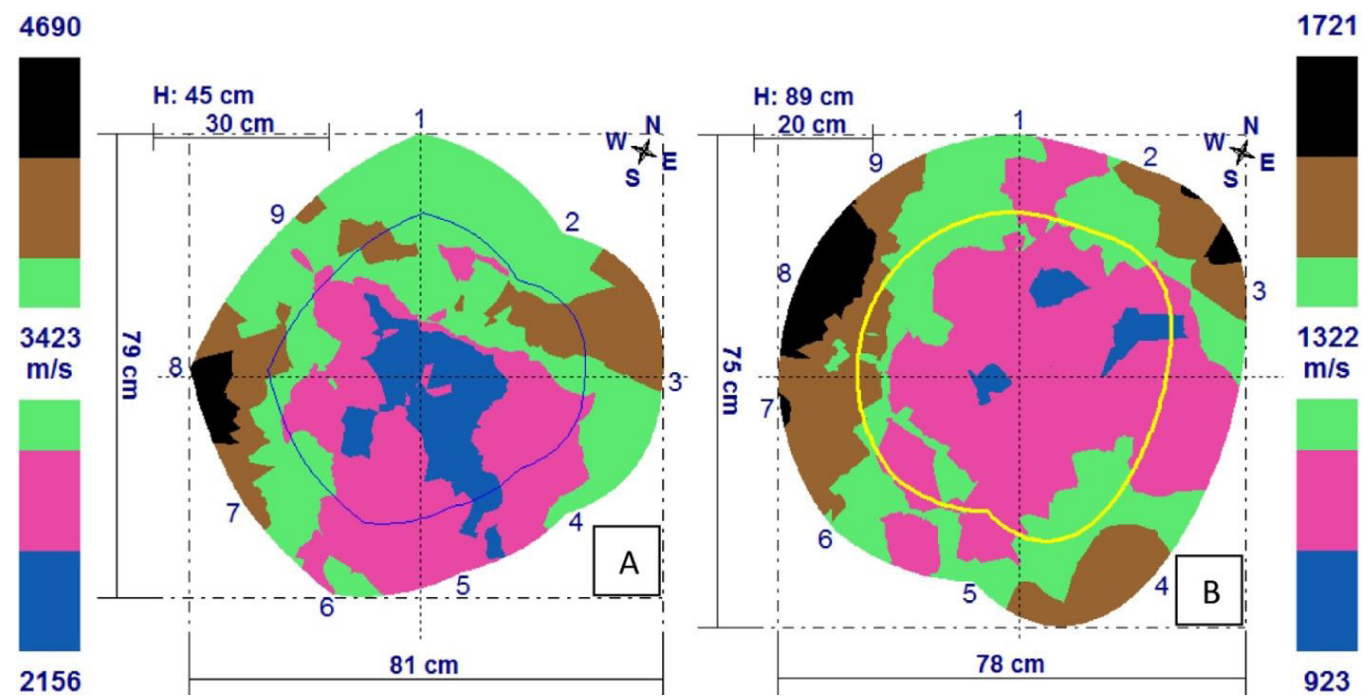

Figure 3. Tomographic scans of two healthy species: Paubrasilia echinata (A) and Schizolobium parahyba (B), revealing different density values, in accordance with their respective mechanical wave speeds

Figura 3. Mapa tomográfico de duas espécies saudáveis: Paubrasilia echinata (A) and Schizolobium parahyba (B), revelando diferentes valores de densidade, de acordo com suas respectivas velocidades de onda mecânica 
Visual comparison of the value scales shows the propagation speed of the waves are quite different between species, corresponding as expected to different BD values (Table 1). The R-squared value of the linear regression of basic density and wave propagation speed from the 27 species was 0.3271 . It demonstrates that each tree is a specific case and the analysis must be done in an individualized mode. The colors in the pictures can be deceiving if scales are not checked as the colors were not exactly standardized to see the intrinsic differences of the species. In general, the central part of the trees analyzed (core) was the region that had lower wave propagation speeds. According Rayner and Boddy (1988), this can be explained by attenuation of extractives in mature trees and preference for xylophagous organisms in that part of the trunk, with adequate oxygen and moisture content.

Although the city of Piracicaba/SP lies geographically in a depression (Paulista Peripheral Depression), we found that in $70 \%$ of cases there was a predominance of highest values for mechanical wave propagation speed (opposite wood in angiosperms) in quadrants 2 and 3 and lower values in quadrants 1 and 4 (Figure 4), showing the influence of regional easterly and southeastly winds, as suggested by Wiendl and Angelocci (1995).

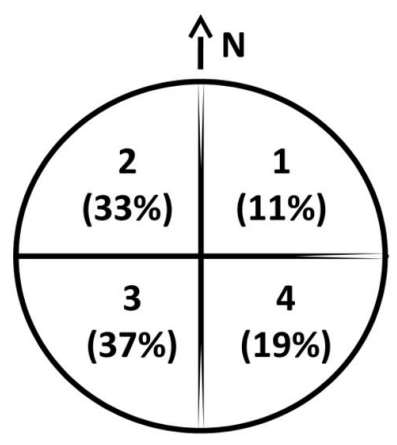

Figure 4. Quantity of trees with predominance of highest values for mechanical wave propagation speed, based on the four quadrants defined in relation to the geographic north

Figura 4. Quantidade de árvores com predominância de valores mais altos para a velocidade de propagação mecânica das ondas, com base nos quatro quadrantes definidos em relação ao norte geográfico

\section{CONCLUSION}

Impulse tomography was able to identify the formation of tension and opposite woods in the angiosperms trunks due the prevailing winds, suggesting and proving the influence of the east and southeast winds in the region. The different values for propagation speed of the mechanical wave was because each tree species has its basic wood density, which this variables are directly proportional.

\section{ACKNOWLEDGEMENTS}

The authors thank to São Paulo Research Foundation - FAPESP (grant 09/53931-6) for financial support with Impulse Tomography equipment and Bruno Balboni for the concepts about angiosperms characteristics wood.

\section{REFERENCES}

AMODEI, J. B; OLIVEIRA, B. R. U.; GURGEL, M. M.; CARVALHO, A. M.; MEDEIROS, R. A.; LATORRACA, J. V. F. Avaliação preliminar da qualidade da madeira de Tectona grandis L. f. através da tomografia de impulso. Floresta e Ambiente, Rio de Janeiro, v. 17, n. 2, p. 124-128, 2010.

CASTRO, V. R.; TOMAZELlO FILHO, M.; ARIZAPANA, M. A.; SILVA, J. C.; SILVA FILHO, D. F.; POLIZEL, J. L.; BELINI, U. L. Avaliação do perfil radial do lenho de árvores de teca (Tectona grandis L.f.) através da tomografia de impulso. Floresta e Ambiente, Rio de Janeiro, v. 18, n. 2, p. 144-152, 2011.

CEPAGRI - CENTRE FOR METEOROLOGICAL AND CLIMATE RESEARCH APPLIED TO AGRICULTURE (CEPAGRI). Clima dos Municípios Paulistas. 2009. Available in: < http://www.cpa.unicamp.br/outrasinformacoes/clima_muni_436.html > Accessed on: Aug 22, 2013. 
Mendes and Silva Filho - Frequency variation of mechanical waves of the

impulse tomograph based on geographic north

CLAIR, B.; RUELLE, J.; BEAUCHÊNE, J.; PRÉVOST, M.F.; FOURNIER, M. Tension wood and opposite wood in 21 tropical rain forest species. Iawa Journal, v. 27, n. 3, p. 329-338, 2006.

GOOD, T. Benefits of Trees. Sydney: National Tree Day, 2010.

JYSKE, T.; MÄKINEN, H.; SARANPÄÄ, P. Wood Density within Norway Spruce Stems. Silva Fennica, Helsinki, v. 42, n. 3, p. 439-455, 2008.

KUHNS, M. Windbreak Benefits and Design. Logan: Utah State University Extension, 2010.

MATTHECK, C.; BRELOER, H. The body language of trees: a handbook for failure analysis. London: The Stationery Office, 1997.

NOAA - NATIONAL OCEANIC AND ATMOSPHERIC ADMINISTRATION. Magnetic Field Calculators. 2014. Available at: < www.ngdc.noaa.gov/geomag-web/ > Accessed on: 5 Aug. 2014.

OLIVEIRA, J. B. C.; PRADO, H. Carta pedológica semidetalhada do Estado de São Paulo. Folha Piracicaba (SF 23-Y-A-IV). Campinas: Instituto Agronômico de Campinas, 1989. Mapa, escala 1:100.000.

PEREIRA-ROLLO, L.C.; SILVA FILHO, D.F.; TOMAZELLO FILHO, M.; MORAES, S.O.; COUTO, H.T.Z. Can the impulse propagation speed from cross-section tomography explain the conditioned density of wood? Wood Science and Technology, New York, v. 48, n. 4, p. 689-701, 2014.

PEREIRA, L. C.; SILVA FILHO, D. F.; TOMAZEllO FIlHO, M.; COUTO, H. T. Z.; MOREIRA, J. M. M. A. P.; POLIZEL, J. L. Tomografia de impulso para avaliação do interior do lenho de árvores. Revista da Sociedade Brasileira de Arborização Urbana, Piracicaba, v. 2, n. 2, p. 65-75, 2007.

RAYNER, A. D. M.; BODDY, L. Fungal decomposition of wood: its biology and ecology. Chichester: John Wiley \& Sons Ltd., 1988.

RINNTECH COMPANY. Technology for tree and wood analysis. 2013. Avaiable in: < http://www.rinntech. de/index-28703.html> Accessed on: Sept 4. 2013.

RUELLE, J. Morphology, Anatomy and Ultrastructure of Reaction Wood. In: GARDINER, B.; BARNETT, J.; SARANPÄÄ, P.; GRIL, J. (Eds.). The Biology of Reaction Wood, Springer: Berlin, Heidelberg. 2014. Chap. 2. p. 13-35.

VALE, A. T., ROCHA, L. R.; MENEZZI, C. H. S. Massa específica básica da madeira de Pinus caribaea var. hondurensis cultivado em cerrado. Scientia Forestalis, Piracicaba, v. 37, n. 84, p. 387-394, 2009.

WANG, X.; ALISON, R. B. Decay Detection in Red Oak Trees Using a Combination of Visual Inspection, Acoustic Testing, and Resistance Microdrilling. Arboriculture \& Urban Forestry, Champaign, v. 34, n. 1, p. 1-4, 2008.

WIENDL, F; ANGELOCCI, L.R. Regime de ventos na região de Piracicaba, SP: análises da direção, da relação de velocidades na vertical e de ventos diurno e noturno. São Paulo: FAPESP, 1995. 60 p.

Received: 09/22/2017

Accepted: 09/24/2018 